\title{
Egocentricity in the English Generic Pronouns: Semantics and Pragmatics in the English Generic Pronouns:
}

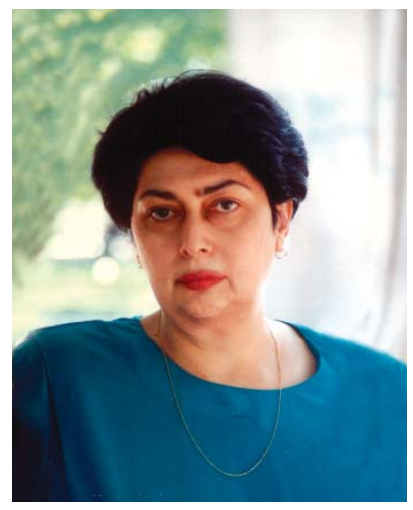

Marika Tonyan

A person's awareness of the world begins with the delimitation of his or her ego from other people, and the use of the pronoun "I" signifies the starting point of self-perception. According to O.Jespersen, "The elder Fichte used to celebrate not his son's birthday but the day on which he first spoke of himself as "I" (Jespersen O., 1922:128).

Within the language system, it is hardly possible to outline, however roughly, the functional spheres of the word "I". Strictly speaking, neither language, nor more so speech, which evidently centres on the "I" of the speaker, is thinkable without the existence of this pronoun. All that is said or written is an act of speech in which the speaker's/writer's ego is expressed either explicitly or implicitly. According to J.Lyons," The canonical situation of utterance is egocentric in the sense that the speaker, by virtue of being the speaker, casts himself in the role of ego and relates everything to his viewpoint” (Lyons J., 1977:638).

Besides the general egocentricity of speech organization, every language has lexical units termed "egocentric words" or "egocentric particulars" that are related to the pronoun "I" so intimately that their meaning remains obscure without reference to the speaker.

As to the pronominal class, the pronoun "I", naturally, has an even greater weight in it, not only because it is basic to the speech act itself, but also because the status of a number of pronouns is defined through their relations with the first person pronoun.

This is the case with the generic pronouns "one", "you" and "we". Ö.Dahl, for instance, unites the generic and personal pronouns and calls them "egocentric”: “... generic pronouns are semantically quite close to first and second person pronouns. Even when generic pronouns are not just a way of talking about oneself without sounding too pretentious they are used to describe the world the way it looks from the participants' point of view" (Dahl Ö., 1997:10).

Our description of the generic pronouns is based on the approach to the concept of pronominal meaning put forward by O.Selivyorstova (Селиверстова О.Н., 1988:224). According to her, the lexical meaning of the pronoun consists of two layers: the so-called level of characterization and that of indication. The former characterizes the participant of the situation as either a class, a member of a class or as an individual. The latter contains indication as to where the participant is located or can be found.

In the light of this approach we suggest that the meaning of the generic pronouns 
should be described as having two basic characteristics: 1) the referent of these words is characterized as a generic person, and 2) the participant of the situation is either the speaker, or any other person whom the speaker presents as one of his/her kind. At first sight, the special emphasis on the inclusion of the speaker into the denotation sphere of these pronouns seems unnecessary, as the concept of generic person should make no exception for anybody. However, the semantic analysis of the pronouns "one", "you" and "we" shows the validity of recognizing "I-inclusion" as a separate component.

1. Let us provide evidence to demonstrate that the referent of the pronouns under consideration is represented as a generic person. Apparently, their referent is not a specific one, there being a restriction on combining these words with particular time markers. The sentence "One came yesterday" is anomalous. However, this is not a satisfactory reason for terming these pronouns "indefinite". As a matter of fact, indefinite lexical units imply that there is no information about their referent or that it is not sufficient. Therefore, the speaker can ask the hearer to provide such information and the latter may be supplied. E.g. "Somebody's knocking at the door.” "Who is it?” "It's the man next door."

On the contrary, the information we receive from the generic pronouns is selfsufficient. It is neither lacking, nor vague. Normally, we do not put any questions to the agent expressed by "one”, "you” or "we”. For example, "One/you/we lives/live and learns/learn" does not encourage the hearer to put a question for the identification of the subject of the sentence. On the other hand, it is quite natural to ask a "who" question if the agent is expressed by the indefinite pronoun "they".

E.g. "They say John’s going to marry Jane." "Who "they”?" or "Who says that?" "Jane herself, actually."

From these facts it follows that it is justifiable to qualify the pronouns "one", "you" and "we" as generic.

2. The existence of the second component of meaning, namely that of "I-inclusion", in the generic pronouns can be proved by a number of linguistic facts. In this paper we shall try to touch upon some of them, eventually trying to characterize the pragmatic and functional impact of the egocentric component.

The inclusion of the speaker into the meaning of the generic pronouns is related to another factor: the generic pronouns are usually used in sentences which are put into a context or a speech situation. However, a question may arise about the wide use of generic pronouns in proverbs, aphorisms and the like. True, these generalizations may often be found in isolation; nevertheless, there is a potential context behind them. They tell us something "about you and me", in other words, the presence of the potential participants in the speaker's mind is essential.

In this connection the interpretation of the so-called empty context is important. "Katz suggests that in order to ascertain whether a linguistic feature is context-dependent or context-independent, we imagine the feature occurring on an anonymous postcard (as an approximation to the empty or null context)" (Levinson S., 1983:8). Searle, however, argues that "There is no such thing as the zero or null context for the interpretation of sentences...we understand the meaning of such sentences only against a set of 
background assumptions about the context in which the sentence could be appropriately uttered” (Searle J.R., 1979:117).

This is the case with the generic pronouns: even when used in isolation, the sentences containing a generic pronoun imply the participation of the speaker/writer and a hearer or a potential reader in the given situation.

Let us observe some linguistic data received from our work with native speakers, whose evidence is essential for the verification and confirmation of the hypothesis put forward above.

Generic reference can also be realized by nouns, e.g. "Man is a mammal." This sentence is relatively independent of the context. More specifically, it can be used against a set of background assumptions about the nature of man; that is to say, the potential context is very wide.

Two informants were asked to substitute the word "man" for a generic pronoun. They found it impossible to do so without putting the sentence into a specific speech situation. After the transformations (the situation was worked out together with the informants), the result was as follows. Let us suppose that a young mother is not allowed to feed her new-born baby, and this makes her unhappy. Her interlocutor wonders why she should worry so much and can say: "What's all this fuss about suckling your baby?” The mother will answer: "Well, one is a mammal, isn't one? One naturally has mammalian instincts and wants to suckle one's own baby."

Besides putting the given sentence into a context, the requirement for the possibility of using "one”, according to the informants, was reference to an actual participant, presumably the speaker or anyone else whom the speaker considered to be one of her like.

For the same reason, in some other cases the informants were reluctant to use a generic pronoun. For example, in the sentence "When a man commits a suicide, people do not always know the cause" none of the 5 informants used a generic pronoun. Their reaction to "When we/you/one commit/commits a suicide..." was that of psychological aversion. In other words, even though the sentence did not violate grammatical norms, semantically and pragmatically it was unusual and disagreeable: the speaker does not usually include himself/herself in the scope of the potential participants of a morbid situation.

Likewise, when given an extraordinary situation with a missing subject they were inclined to supply lexical units other than the generic pronouns. For example, "If we/you/one met a Martian..." would be less common than "If anyone/ an astronaut met a Martian..." in which cases the hypothetical situation required either a hypothetical agent ("anyone") or an agent more appropriate for the unusual situation ("astronaut").

A question may naturally arise: how generalization can be combined with a focus on something as unique as the personality of the speaker. We suggest the following attitude to the problem. In fact, the generic pronouns characterize their referent as a representative of a group similar to the speaker ("others are like me"); in other words, the use of the generic pronouns presupposes a potential participation of any human being (provided he or she is one of the peer-group centred on the speaker) in 
the given situation. The bases for including others in this peer-group vary: they may be the participants' social status, their common background, level of education, age, sex, etc.

An interesting interpretation of the differences between "I" and "one" is found in B.Rotman's article "Going Parallel". B.Rotman speaks about the age of computers when "human nature is melting" and the result is posthumanity. He writes: "Once, not so long ago, little more than a generation in fact, there was a clear and distinct binary, an absolute opposition of self versus non-self. An I/me consciously and securely present to myself, fully defined and ranged against an external, collective other; an autonomous first person, indivisible, privately interior, invariant nucleus of being versus a they, an amorphous shifting collectivity of third persons outside my skin. The variable for such a subject, for a self that could range indifferently and arbitrarily over the social other, was the abstract pronoun one" (Rotman B., 2000:60).

In this definition we see a clear opposition of "self" against "non-self". On the one hand, there is the concept of "I" ("an autonomous first person, indivisible, privately interior, invariant nucleus of being") and on the other, "they" ("an amorphous shifting collectivity of third persons outside my skin"). The pronoun "one" is a variable for the "I", for a "self that could range indifferently and arbitrarily over the social other". It is noteworthy that B.Rotman qualifies those who are involved in "one", by expanding the limits of the individual and the individual's rights: "Since the Renaissance, a whole social fabric, associated legal code and apparatus of moral responsibility, a system of private ownership and individual rights and duties has been constructed to rest on such a one (Rotman B., 2000:61).

The egocentric component of meaning which is present in the generic pronouns makes it possible for them to perform the perlocutionary function of linguodemagogy. According to T.Nikolaeva, who suggested the term, "linguodemagogy is a perlocutionary phenomenon the essence of which lies in the evaluative influence upon the hearer, which is carried out indirectly" (Николаева T.M. 1988:155). The chief reason for linguodemagogical influence is intolerance to the feeling of social solitude. Whenever such a feeling arises, a person tends to lean against a certain social layer, a communicatively "full" space, for support. Even if there is no such stratum in reality, one builds it up by linguistic means. As a result, the speaker makes the hearer believe that what he or she says is shared by a whole social group, and this group is made up of people similar to the speaker (and very often the hearer). Thus, the user of a generic pronoun functions as a spokesman who verbalizes the opinion of the group generated by him or her.

A similar differentiation between a peer group and all the others, who do not belong to it, is done by Paul Riqueur, who notes that it is possible to distinguish between two meanings of the concept of "another person": "there exists another person whom I consider a personality and can look upon him as "you" and others who are like all the rest and whom I do not see as a personality, and I am connected with them institutionally, e.g. with the postman delivering mail” (Рикер П., 1995:108). M.Halliday formulates 
this in a very simple manner: "You” and "one” often by implication denote any person I would approve of (Halliday M.A.K., Hasan R., 1978: 39).

The semantic peculiarity of the generic pronouns under consideration and the perlocutionary effect they are able to realize accounts for the use of these pronouns in scientific and official registers. In these registers of speech the speaker/writer deliberately avoids putting forward his or her personality. At the same time, the use of the generic pronouns suggests a connection between the speaker and hearer or the writer and reader. In this way the message is directed to a group of supporters, or the social group of those "who are like me".

Ö.Dahl remarks: "In many kinds of written texts, personal pronouns such as $I$ and you are virtually banned. This is connected with the fact that many written documents - news items, unsigned encyclopedia articles, legal documents of various kinds - are not considered as having a personal "sender" or "receiver" in the sense that a spoken utterance has a speaker and a listener. Even in genres where the author can be identified, using a pronoun like $I$ is sometimes considered bad tone. The plural pronoun we often occurs where I does not” (Dahl Ö, 1997: 48).

In consequence, the perlocutionary effect of convincing the addressee and achieving the goal of transmitting the sender's intention is successfully realized. This is the reason why proverbs, maxims, aphorisms, etc. abound in generic pronouns. Being expressions of collective or individual wisdom they generalize a piece of experience and raise it to the status of a norm shared by people belonging to this or that group. The size of the group varies: it can include the whole mankind, a nation, and a much narrower social circle.

On the other hand, whenever the purpose of the utterance is to confine the sphere of activity by the speaker, the pronoun "I" is exclusively preferred. Thus, the pronoun "I" is deictically marked, while the generic pronouns are not. While the first person pronoun is a member of a distinct opposition ("I" vs. "you”), there is no strict opposition between the generic pronouns and any other linguistic unit. Consequently, only the first person pronoun can be used when indication to the speaker or contrast with non-speakers is relevant.

At the same time, the pronoun "I" expresses the highest degree of individualization, as in the following questions from the Talmud.

- If I am not for myself, who will be for me?

- If I am for myself only, what am I?

- If not now, when?

Obviously, the pronouns "one”, "you” and "we” might be used in these cases, but the meaning of self-awareness, uniqueness and individuality would be lost. In fact, the quoted wisdom requires emphasis on these particular features. Hence, the pronoun "I" cannot be substituted without change of meaning of the whole challenging utterance.

In conclusion we can say that the generic pronouns are to be found among egocentric lexical units, and the focus on the speaker/writer predetermines the organization of the speech event in which they occur. 


\section{References:}

1. Николаева Т.М. Лингвистическая демагогия. В кн.: Прагматика и проблемы интенциональности. М., 1988.

2. Рикер П. Герменевтика, этика, поэтика. М.,1995.

3. Селиверстова О.Н. Местоимения в языке и речи. М.,1988.

4. Dahl Ö. Egocentricity in Discourse and Syntax. 1997. In: http:www.ling.su.se/staff/oesten/egocentric.

5. Halliday M.A.K., Hasan R. Cohesion in English, London, 1978.

6.. Jespersen O. Essentials of English Grammar, London, 1946.

7. Levinson S. Pragmatics. Cambridge, Cambridge University Press, 1983.

8. Lyons J. Semantics, v.2, Cambridge, Cambridge University Press, 1977.

9. Rotman B. Going Parallel. In: SubS 21. Ohio, JHU Press, 2000, http://www.press.jhu.edu/journals/substance/v029/29.1rotman.html

10.Searle J.R. Expression and Meaning. Cambridge, Cambridge University Press, 1979.

\section{UGqLtentah nanhuanuluma ntenuanıGatiph tumbtaunnna houmuunujha pununnhen. hưuuunupuanıpjnıG le qnpơmpuGnเpjnıG}

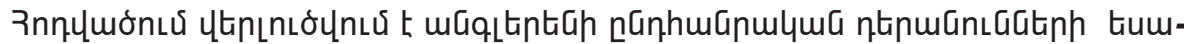

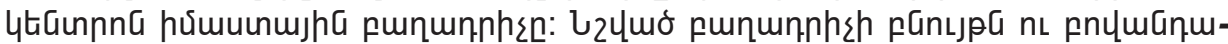

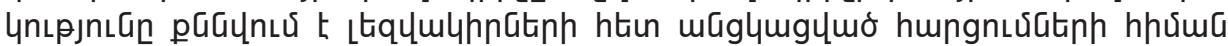

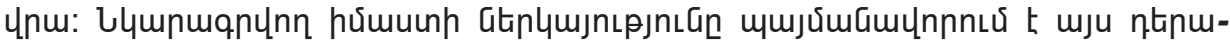

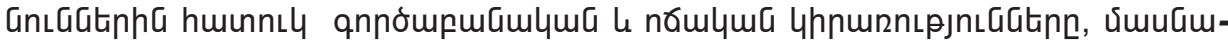

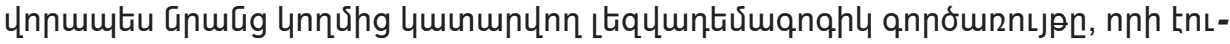

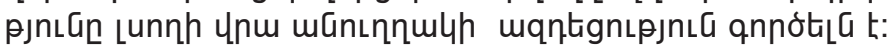

